\title{
Presurgical cytologic diagnostic test of uterine cavity in ovarian malignant tumor
}

\author{
Andrijono ${ }^{*}$, Isrin Ilyas ${ }^{*}$, Chairil Hamdani ${ }^{f}$
}

\begin{abstract}
Abstrak
Ada beberapa metode untuk mendiagnosis karsinoma ovarium, diantaranya pemeriksaan ginekologi, pemeriksaan ultrasonografi, pemeriksaan tumor marker, dan gabungan beberapa pemeriksaan. Akan tetapi, gabungan pemeriksaan tersebut belum memberikan hasil spesifitas dan sensitivitas yang tinggi. Untuk itu masih diperlukan pemeriksaan lain untuk meningkatkan baik sensitivitas ataupun spesifitas, dan salah satu yang menarik untuk diteliti adalah pemeriksaan sitologi kavum uteri. Dengan pemeriksaan sitologi kavum uteri diharapkan dapat ditemukan sel-sel ganas yang berasal dari tumor ganas ovarium. Penemuan sel tumor ganas ovarium dimungkinkan karena adanya mekanisme peristaltik pada tuba fallopii dan tekanan negatif dari kavum uteri, sehingga memungkinkan terjadinya transportasi sel ganas ovarium ke dalam kavum uteri melalui tuba. Penelitian ini bertujuan mengetahui sensitivitas dan spesifitas pemeriksaan sitologi kavum uteri dalam mendeteksi keganasan ovarium dibandingkan dengan pemeriksaan histologi yang umum dilakukan. Penelitian ini merupakan uji diagnostik, dengan pemeriksaan histologi sebagai baku emas, untuk mengetahui sensitivitas, spesifisitas, nilai praduga positif, dan nilai praduga negatif pemeriksaan sitologi kavum uteri. Sebanyak 30 kasus masuk dalam penelitian ini. Ada beberapa faktor yang meningkatkan nilai positif sitologi kavum uteri, antara lain stadium, dan asites. Semakin tinggi stadium semakin besar nilai positif, adanya asites memperbesar kemungkinan positif. Pada uji diagnostik didapatkan sensitivitas sitologi kavum uteri sebesar $48 \%$, spesifisitas $60 \%$, nilai praduga positif $85,7 \%$, dan nilai praduga negatif $18,8 \%$. Kesimpulan: pemeriksaan sitologi kavum uteri dapat digunakan sebagai salah satu metode untuk membantu dalam mendiagnosis karsinoma ovarium. (Med J Indones 2005; 14: 92-6)
\end{abstract}

\begin{abstract}
There are several methods for diagnosing ovarian carcinoma, such as gynecological examination, ultrasonographic examination, and tumor marker examination. However, all these combinations have not yielded high specificity and sensitivity results. For this reason, it is necessary to perform other examinations to enhance both specificity and sensitivity, and one of them which is of interest to be studied is cytological examination of uterine cavity. By cytological examination of uterine cavity, it is hoped that malignant cells originating from ovarian malignant tumor can be found. Discovery of ovarian malignant cells is possible because of peristaltic mechanism in the fallopian tube and negative pressure from uterine cavity, that makes possible the transportation of ovarian malignant cells into uterine cavity through the tube. The objective of this study is to understand the sensitivity and specificity of cytological examination of uterine cavity in detecting ovarian malignancy. This study was a diagnostic test with histological examination as the gold standard, to understand sensitivity, specificity, positive prediction value, and negative prediction value of cytological examination of uterine cavity. A total of 30 cases were included in the study. A number of factors enhanced positive results in cytology of uterine cavity. Those factors were stage and ascites. The more advanced the stage, the greater the positive results, and the presence of ascites increased positive results. On diagnostic test, sensitivity of uterine cavity cytology was 48\%, specificity 60 , positive predictive value $85.7 \%$, and negative predictive value $18.8 \%$ respectively. In conclusion, cytological examination of uterine cavity could be used as one of the methods in assisting the diagnosis of ovarian carcinoma. (Med J Indones 2005; 14: 92-6)
\end{abstract}

Keywords: cytology, uterine cavity, ovarian malignant tumor

\footnotetext{
* Department of Obstetry and Gynecology, Faculty of Medicine University of Indonesia/Dr. Cipto Mangunkusumo Hospital, Jakarta, Indonesia

${ }^{f}$ Department of Pathology, Faculty of Medicine University of Indonesia/Dr. Cipto Mangunkusumo Hospital, Jakarta, Indonesia
}

Ovarian carcinoma is one of gynecological cancers which causes highest rate of mortality. This may be due to the fact that generally patients are admitted for treatment at advanced stage. In addition, surgical failure associated with inappropriate pre-surgical diagnosis may result in prolonged failure. Surgical failure is one of the problems frequently encountered, 
while surgery in ovarian malignancy has an important significance because it has diagnostic and therapeutical purposes. For the purpose of diagnosis, the objective is generally achieved, because histological diagnosis represents the main diagnosis. However, the purpose of treatment is frequently not achieved. Surgery with therapeutical purposes requires completeness of surgery, in addition to the attempt to eliminate tumor residue. If the purpose of therapy in the first surgery is not achieved, a repeat surgery is required, which certainly will result in high costs, and at times there are complicating factors that are difficult to overcome. A number of methods that are designed to predict ovarian malignancy includes clinical gynecological examination, ultrasonographic examination, and tumor marker examination. ${ }^{1,2,3}$ Several diagnostic methods are performed through fluid cytology, particularly the fluids from peritoneal cavity. However, these methods are generally invasive. ${ }^{4}$ One of the non-invasive cytological methods is cytological examination of uterine cavity. This non-invasive method needs to be developed, and we attempted to develop a diagnostic method of cytology for uterine cavity. With cytological examination of uterine cavity, it is hoped that ovarian malignant cells can be identified. Identification of ovarian malignant cells in uterine cavity is made possible by fluid transportation from peritoneal cavity into uterine cavity because of the negative pressure in the uterine cavity, and movement of tubal cilia and peristaltic of the tube. This study was performed to identify the benefits of cytological examination of uterine cavity by calculating the sensitivity and specificity through a diagnostic test.

\section{METHODS}

This study was a diagnostic test, to compare cytological examination of uterine cavity as a diagnostic tool for detecting ovarian malignancy, and histological examination of tumor that served as the gold standard of examination.

\section{Study samples}

Study samples consisted of ovarian tumor patients with suspected malignancy which were determined by several clinical signs, such as rapid tumor growth, body weight decrease, ascites or pleural effusion, ovarian tumor with solid part, ovarian tumor with papillary growth, ovarian tumor with adhesions and limited mobility, and decrease in resistance index on ultrasonographic examination.

\section{Procedures}

After physical examination, and ovarian malignancy was suspected, cytological examination of uterine cavity was performed with cytobrush, by introducing the cytobrush into the uterine cavity through the cervix and cervical canal. Once the cytobrush is inside the uterine cavity, it is rotated clockwise several times, and then put into a tube containing $10 \mathrm{ml} \mathrm{NaCl}$ and $10 \mathrm{unit} / \mathrm{ml}$ heparin, fixated during 30 minutes and centrifugated. Its deposits were aspirated and 4-6 slides were made to be stained with Papaniculaou. Slides were then screened by cytologists at Department of Anatomic Pathology, Faculty of Medicine University of Indonesia. As a comparison, we performed cytological examination of intraperitoneal fluid or peritoneal cavity rinsing. Cytological smears of intra peritoneal fluid/peritoneal cavity rinsing were made by centrifugation ( $3000 \mathrm{~g}$ ) of $20 \mathrm{ml}$ of the fluid for 5 minutes, followed by slide smear-preparations of the deposits and papaniculaou staining. As the gold standard, histological examination of tumor tissues was conducted.

\section{Statistical test}

Descriptive analysis and diagnostic test to calculate the values of sensitivity and specificity by Kappa values was performed.

\section{RESULTS}

During the period of the study, a total of 30 samples were found. Of this number, 25 samples were patients with malignant ovarian tumor and 5 patients with benign ovarian tumor. A total of $18(72 \%)$ samples showed histological type of epithelial ovarian carcinoma, among them, there were 6 of the serous type, 8 of the mucinous type, and 4 of other type carcinoma. The remaining 6 (24\%) samples was non-epithelial malignant tumor and $1(4 \%)$ sample was metastatic tumor of non ovarian origin. All serous type carcinomas metastasized to the serous layer of the uterus, while the mucinous type did not metastasize.

From the viewpoint of relationship between cytological examination of uterine cavity and the presence of ascites, from the patients with ascites, positive results on cytological examination of uterine cavity was $60 \%$. Furthermore from 18 cases without ascites, only 6 (30\%) cases were positive on cytological examination of uterine cavity. All primary ovarian malignant 
tumors (epithelial and non-epithelial) were processed by descriptive statistical analysis because by presurgical clinical examinations it was difficult to predict or distinguish epithelial ovarian malignant tumor from non-epithelial ovarian malignant tumor.

The relationship between stage of tumor and cytology of uterine cavity in primary ovarian malignant tumor is showed in Table 1; here, the one case of metastatic tumor was not included in descriptive statistical analysis.

Table 1. Relationship between stage of tumor and cytology of uterine cavity in primary ovarian malignant tumor

\begin{tabular}{cccc}
\hline Stage & $\begin{array}{c}\text { Number of } \\
\text { patients }\end{array}$ & $\begin{array}{c}\text { Number of } \\
\text { positive cases }\end{array}$ & $\%$ \\
\hline I & 4 & 1 & 25 \\
II & 6 & 2 & 33.3 \\
III & 10 & 6 & 60 \\
IV & 4 & 3 & 75 \\
\hline Total & 24 & 12 & \\
\hline
\end{tabular}

It is obvious from Table 1 that the more advance the stage, the higher the possibility of positive result in cytology of uterine cavity.

Table 2 showed the relationship between the results of cytology of uterine cavity and those of histology, and Table 3 showed the relationship between the results of peritoneal cytology and those of histology.

Table 2. Relationship between the results of cytology of uterine cavity and those of histology

\begin{tabular}{|c|c|c|c|}
\hline \multirow{2}{*}{$\begin{array}{l}\text { Cytology of } \\
\text { uterine cavity }\end{array}$} & \multicolumn{2}{|c|}{ Histology } & \multirow{2}{*}{ Total } \\
\hline & Positive & Negative & \\
\hline Positive & 12 & 2 & 14 \\
\hline Negative & 13 & 3 & 16 \\
\hline Total & 25 & 5 & 30 \\
\hline
\end{tabular}

Positive $=$ cancer cells were found, negative $=$ no cancer cell was found

From Table 2, sensitivity value was $48 \%$, specificity $60 \%$, positive predictive value $85.7 \%$, and negative predictive value $18.8 \%$.
Table 3. Relationship between the results of peritoneal cytology and those of histology

\begin{tabular}{lccc}
\hline \multirow{2}{*}{$\begin{array}{l}\text { Peritoneal } \\
\text { cytology }\end{array}$} & \multicolumn{2}{c}{ Histology } & Total \\
\hline Positive & 6 & Negative & \\
Negative & 19 & 4 & 7 \\
\hline Total & 25 & 5 & 23 \\
\hline
\end{tabular}

Positive $=$ cancer cells were found, negative $=$ no cancer cell was found

From Table 3 , sensitivity value was $24 \%$, specificity $80 \%$, positive predictive value $85.7 \%$, and negative predictive value $17.4 \%$.

\section{DISCUSSION}

Up to now no diagnostic method of ovarian carcinoma has been invented, which has a sensitivity or specificity value of $100 \%$. Experts have made efforts to establish various parameters to detect the presence of malignancy in ovarian tumor before surgery, but the results are not promising. As a result, it is not uncommon that diagnosis of malignant ovarian tumor is made after surgery. For this reason, it is necessary to conduct numerous studies to enhance the sensitivity and specificity of clinical diagnosis of malignant ovarian tumor to the extent that surgery can be prepared appropriately.

This study was performed to confirm the presence of malignant cells in ovarian carcinoma which can be detected by cytological examination of uterine cavity. Mechanism of flow due to cilia movement in the tube which flows fluid from peritoneal cavity into uterine cavity makes possible the transportation of ovarian malignant cells from the ovaries into the tubal duct. ${ }^{5}$ This mechanism could be proved by this study because in this study the 6 cases of ovarian carcinoma of serous type were found to metastasize to the serous layer of the uterus, and we found the presence of malignant cells inside uterine cavity. However, in the evaluation, no further process from serous layer into the endometrium was found.

Malignancy of serous type was interesting because in the present study, all cases of serous malignant tumors metastasized into the uterus, while in mucinous type there was no single metastatic case found. The 
identification of malignant ovarian tumor cells in uterine cavity does not mean the presence of invasion of malignant tumor into the endometrium. This is because in several cases, malignant cells were found in cytological examination, but histologically no invasion was found into endometrial tissue. This phenomenon explains the presence of exfoliated cells from malignant ovarian tumor in the uterine cavity. Therefore it was hoped that the taking of specimen from the endometrium would also take the ovarian tumor derived malignant cells.

Cytobrush instrument was used in the present study because it was relatively inexpensive and easily available, and because its procedure was relatively easy and non-invasive. With this in mind, it was hoped that the result of this study would provide benefits in establishing the diagnosis of malignant ovarian tumor.

In the present study, the majority of cases were those with epithelial ovarian carcinoma (72\%), and the rest non-epithelial ovarian carcinoma (24\%). Furthermore, there were more cases of mucinous carcinoma than serous carcinoma. Theoretically, it is more likely for malignant ovarian cells of serous type to provide positive results in cytology of uterine cavity because they were relatively small compared with those of mucinous type. On the other hand, it is less likely for mucinous carcinoma to be detected by cytology of uterine cavity, because the cells form larger aggregates which make them more difficult to migrate into fallopian tube and uterine cavity. ${ }^{6}$

Cytological examination of uterine cavity tended to correlate positively with clinical stage of ovarian carcinoma. The more advanced the clinical stage, the more likely it is to be positive. Cytological examination of peritoneal fluid which was one of the standards for determining clinical stage of ovarian carcinoma had a relatively lower sensitivity, i.e. approximately $24 \%$. This finding was consistent with the result of negative predictive value which was only $17.4 \%$. This shows a great likelihood of false negative results, which was not different from those reported in literature. ${ }^{7,8}$

False negative result of cytology of peritoneal fluid resulted in recurrence of ovarian cancer which had been mistakenly predicted to be at stage IA, such that adjuvant therapy could not be administered. Therefore, it is necessary to find a more appropriate method to enhance the sensitivity of cytological examination of peritoneal fluids. By contrast, specificity value of cytology of peritoneal fluid was relatively greater, i.e. $80 \%$, such that the positive results provided a greater certainty. In the light of these results, it is necessary for us to discuss again the accuracy of cytological examination of peritoneal fluid to determine clinical stage of ovarian cancer.

Ascites is one of the factors that may lead to the identification of malignant cells in the uterine cavity. This was evident in the cases with ascites, whose positive results in the uterine cavity cytology were greater than negative results.

Cytological examination of uterine cavity compared with the gold standard (histological examination) showed a sensitivity value of $48 \%$, which was greater than that of cytological examination of peritoneal cavity. However, specificity of cytological examination of uterine cavity was lower, i.e. $60 \%$. This condition might be due to the presence of numerous interfering cells originating from endometrium that were taken during the taking of cytological specimens. It is very likely that endometrial cells interfere with cytological examinations. However, positive predictive value was relatively great, i.e. $85.7 \%$.

When compared with cytological examination of peritoneal fluid, cytological examination of uterine cavity was better in detecting the presence of ovarian cancer cells. Several factors may interfere with cytological results of the peritoneum that render low outcome. These may be due to other causative factors of ascites, such as abnormality of liver or renal functions and the possible presence of hypoalbuminemia which is responsible for dilution, leading to a decrease in positive outcome. Taking of fluid sample from an incorrect location - the appropriate location for the taking of peritoneal cytology sample was Douglas' cavity, but frequently the sample was taken as soon as the peritoneum was opened up - and other disrupting factors such as fixation process, could contribute to this low outcome.

With sensitivity value of $24 \%$, specificity of $80 \%$, and positive predictive value of $85.7 \%$, these results of peritoneal fluid cytology did not differ significantly from those achieved by tumor marker CA 125 in diagnosing ovarian malignancy, i.e. CA 125 had a sensitivity value of $50 \%$, specificity value of $96 \%$, and positive predictive value of $83.43 \% .{ }^{9}$ On the other hand, ultrasonographic examination which was 
frequently used in diagnosing ovarian cancer had positive predictive value of $47 \%$, sensitivity of $34 \%$, and specificity of $80-94.5 \% .^{10}$

In conclusion, the comparison of cytological examination of uterine cavity with the gold standard (histological examination) provided a sensitivity of $48 \%$, specificity of $60 \%$, positive predictive value of $85.7 \%$, and negative predictive value of $18.8 \%$. Cytological examination of peritoneal fluid compared to the gold standard (histological examination) showed a sensitivity of $24 \%$, specificity of $80 \%$, positive predictive value of $85.7 \%$, and negative predictive value of $17.4 \%$.

\section{REFERENCES}

1. De Priest PD, Shenson D, Fried A, Hunter JE, Andrews SJ, Gallion $\mathrm{HH}$ et al. A morphology index based on sonographic finding in ovarian cancer. Gynecol Oncol 1993;51:7-11
2. Kurjak A. Ultrasound and ovarian cancer. Ultrasound Obstet Gynecol 1991;1:231-3

3. Bast RC, Klug TL, Schaetzl E, Lavin P, Niloff JM, Terrence $\mathrm{F}$, et al. Monitoring human ovarian carcinoma with combination of CA125, CA 19-9, CEA. Am J Obstet Gynecol 1984:149:553-9

4. Funkhauser JW, Hunter KK, Thompson NJ. The diagnostic value of cul-de-sac aspiration in the detection of ovarian carcinoma. Acta Cytol 1975;19:538-41

5. Kato Y, Ohno E, Iwaya. Usefulness of endometrial aspiration cytology for the preopertive diagnosis of ovarian carcinoma. Acta cytol 1998; 42:104-9

6. Berek JS, ed. Novak's gynecology. $12^{\text {th }}$ ed. Baltimore: Williams and Wilkins; 1996

7. Zuna R, Mitchell M, Mulick K, Weijchert W. Cytohistologic correlation of peritoneal washing cytology in gynecologic disease. Acta cytol 1989;33:327-35

8. Mulvancy N. Cytohistology correlation in malignant peritoneal washing: analysis of 75 malignant fluids. Acta cytol 1996;40:1231-39

9. Einhorn M, Sjovall K, Knapp RC. Prospective evaluation of serum CA 125 levels for early detection of ovarian cancer. Obstet Gynecol 1992;80:14-8

10. Van Nagell JR, Gall cos HH, Paulik EJ, De Priest PD. Ovarian cancer screening. Cancer 1998;8:15-25. 